\title{
PENGGUNAAN ALAT PERAGA ULAR TANGGA UNTUK MENINGKATKAN HASIL BELAJAR SISWA MAPEL GEOGRAFI
}

\author{
Nurul Komari, Novita Sariani \\ Prodi Pendidikan Geografi IKIP-PGRI Pontianak \\ Email: novitasariani24@yahoo.co.id
}

\begin{abstract}
Abstrak
Kurangnya media untuk menjadi sarana penyampaian materi yang belum terfasilitasi oleh sekolah juga menjadi faktor penyebab rendahnya minat belajar siswa yang berdampak pada hasil belajar siswa. Tujuan dari penelitian ini untuk mengetahui bagaimana penggunaan alat peraga ular tangga tematik dalam pembelajaran geografi dan peningkatan hasil belajar siswa setelah menggunakan alat peraga ular tangga tematik dalam pembelajaran geografi di kelas XI IPS SMA Negeri 1 Sintang. Metode yang digunakan dalam penelitian ini adalah penelitian tindakan kelas. Penggunaan alat peraga ular tangga tematik pada mata pelajaran geografi di kelas XI SMA Negeri 1 Sintang pada siklus I sudah berjalan dengan baik dan perlakuan pada siklus II siswa jauh lebih mengerti peraturan permainan sehingga siswa lebih bersemangat dalam belajar dengan digunakannya alat peraga ular tangga tematik dalam pembelajaran. Terdapat peningkatan hasil belajar siswa pada siklus I persentase siswa yang termotivasi terhadap pembelajaran dengan penggunaan alat peraga ular tangga tematik terdapat $72,72 \%$ siswa tuntas dan siklus II terdapat $81,81 \%$ siswa yang tuntas dan ketuntasan klasikal mencapai $81,81 \%$.
\end{abstract}

Kata Kunci : Ular Tangga, Hasil Belajar

\section{Abstract}

The lack of media to be a means of delivering material that has not been facilitated by schools is also a factor causing the low interest in student learning that has an impact on the student's learning outcomes. The purpose of this study was to determine how the use of thematic snake ladder props in geography learning and improvement of student learning outcomes after using thematic snake ladder props in geography learning in class XI IPS Senior High Scholl 1 Sintang. The method used in this study is the action research method. The use of snake ladder thematic props in geography subjects in class XI Senior High School 1 of Sintang in cycle I had gone well and treatment in cycle II students understand more about the game rules so that students are more enthusiastic in learning by using thad thematic snakes and ladders in learning. . There was an increase in student learning outcomes in cycle I the percentage of students who were motivated towards learning by using the thematic snake ladder props were $72.72 \%$ of students who passed the test and in cycle II there were $81.81 \%$ and completeness Classical reached $81.81 \%$.

Key Words : Snakes and Ladders, Learning Outcome

\section{PENDAHULUAN}

Belajar pada hakikatnya adalah proses interaksi terhadap semua situasi yang ada di sekitar individu. Belajar merupakan suatu proses perubahan tingkah laku pada individu yang berinteraksi dengan lingkungannya. Perubahan itu berbentuk kecakapan, keterampilan, sikap, pengertian, harga diri, minat, watak dan penyesuaian diri. Belajar dapat dikatakan sebagai kegiatan psiko-fisik untuk menuju keperkembangan pribadi manusia seutuhnya yang menyangkut ranah kognitif, afektif, dan psikomotorik [1].

Belajar juga merupakan proses melihat, mengamati, dan memahami sesuatu. Berdasarkan observasi yang dilakukan peneliti yaitu kurangnya media atau alat bantu untuk menjadi sarana penyampaian materi yang belum terfasilitasi oleh sekolah juga menjadi faktor penyebab rendahnya minat belajar siswa yang berdampak pada hasil belajar siswa. 
Kegiatan pembelajaran dilakukan oleh dua orang pelaku yaitu guru dan siswa. Mengatasi hal tersebut maka peneliti membuat alat peraga yang sederhana, unik yang dapat membangkitkan minat belajar siswa, sehingga berdampak pada hasil belajar.

Permainan ular tangga mungkin sudah tidak asing lagi bagi semua orang karena mudah didapatkan. Namun kali ini permainan ular tangga dapat dijadikan suatu model, media, dan strategi pembelajaran bagi siswa. Alat permainan edukatif ular tangga sangat menarik. Salah satu kelebihan pokok adalah pada visualisasi yang menyenangkan dapat mengaktifkan semua indera siswa sehingga stimulasi yang masuk dapat dengan mudah dicerna, anak memperoleh pemahaman dan kebermaknaan bagi hidupnya.

Media ular tangga tematik dapat mendorong siswa untuk dapat memberikan tanggapannya secara bebas, siswa dilatih untuk dapat bekerja sama dan menghargai pendapat orang lain, membuat suasana pembelajaran yang kooperatif antara siswa dengan siswa dan antara siswa dengan guru. Cara ini akan lebih memotivasi siswa untuk berinteraksi dan bereksplorasi seputar topik pembelajaran yang ada, saling membantu, berdiskusi dan berargumentasi mengemukakan idenya sambil bermain.

Pembelajaran tematik memberikan kesempatan pada siswa untuk memahami masalah yang kompleks yang ada di lingkungan sekitarnya dengan pandangan yang utuh. Dengan demikian siswa diharapkan memiliki kemampuan untuk mengidentifikasi, mengumpulkan, menilai, dan menggunakan informasi yang ada di sekitarnya secara bermakna. Hasil belajar siswa pada hakikatnya adalah perubahan tingkah laku sebagai hasil belajar dalam pengertian yang lebih luas mencakup bidang kognitif, afektif, dan psikomotorik". Dari pendapat tersebut dapat disimpulkan bahwa hasil belajar merupakan ukuran untuk mengetahui seberapa jauh seseorang menguasai bahan yang sudah diajarkan. Untuk mengembangkan hasil belajar tersebut diperlukan penggunaan alat peraga dan model pembelajaran yang tepat untuk membantu siswa mencapai hasil pembelajaran [2]. Sejalan dengan hasil penelitian sebelumnya menjelaskan bahwa media pembelajaran merupakan alat bantu yang dapat digunakan oleh guru dalam proses pembelajaran. Melalui media pembelajaran siswa diberi kemudahan dalam memahami materi pembelajaran. Media permainan ular tangga akuntansi merupakan media pembelajaran yang layak untuk digunakan sebagai media pengayaan dalam pembelajaran akuntansi [3].

Tujuan khusus dalam penelitian ini adalah untuk mengetahui. 1) Penggunaan alat peraga ular tangga tematik dalam pembelajaran geografi di kelas XI IPS SMA Negeri 1 Sintang. 2) Peningkatan hasil belajar siswa setelah menggunakan alat peraga ular tangga tematik dalam pembelajaran geografi di kelas XI IPS SMA Negeri 1 Sintang.

\section{METODE}

Metode penelitian adalah cara ilmiah untuk mendapatkan data dengan tujuan dan kegunaan tertentu. Berdasarkan pendapat diatas metode penelitian adalah suatu cara untuk memecahkan masalah dengan menggunakan metode ilmiah [3] .Metode yang digunakan dalam penelitian ini adalah metode penelitian tindakan. Bentuk penelitian yang digunakan dalam penelitian tindakan kelas ini adalah kolaboratif. 


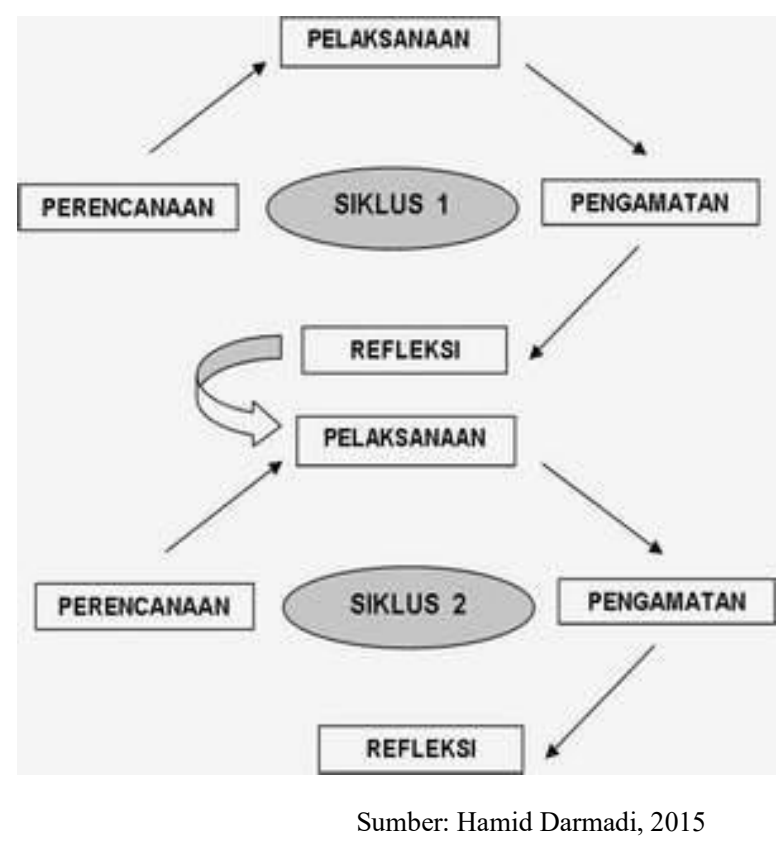

Gambar 1. Siklus Penelitian Tindakan Kelas Menurut John Elliot

Penjelasan gambar di atas sebagai berikut :

a. Tahap 1 : Menyusun rancangan tindakan (Planning)

Membuat Rencana Pelaksanaan Pembelajaran (RPP) bersama guru mata pelajaran Geografi kelas XI IPS dan alat peraga ular tangga tematik. Menyusun tes hasil belajar, pedoman observasi dan merencanakan waktu pelaksanaan

b. Tahap 2 : Pelaksanaan Tindakan (Acting)

Guru mempersiapkan kelas, memotivasi, memberikan penjelasan mengenai penggunaan ala peraga ular tangga tematik, guru membuat kelompok, meminta siswa untuk mengajukan pertanyaan atau permasalahan yang belum mereka pahami, merumuskan hipotesis, mengumpulkan, mengananalisis data dan menyimpulkan.

c. Tahap 3 : Pengamatan (Observing)

Mengamati proses pembelajaran dengan penggunaan ala peraga ular tangga tematik dan mendokumentasikan.

d. Tahap 4 : Refleksi (Reflecting)

Peneliti berdiskusi bersama guru terhadap masalah yang diperoleh pada saat observasi dan peneliti menyusun rencana tindakan selanjutnya dengan melakukan penyempurnaan atau perbaikan.

Subjek penelitian adalah siswa kelas XI IPS 4 SMAN 1 Sintang semester genap tahun ajaran 2017/2018 yang berjumlah 33 siswa, terdiri dari 16 siswa laki-laki dan 17 siswa perempuan. Penelitian ini dilaksanakan di SMA Negeri 1 Sintang di kelas XI IPS 4 pada tahun ajaran 2017/2018, berlokasi di jalan S. Parman Sintang No. 07, Kelurahan Tanjung Puri, Kecamatan Sintang, Kabupaten Sintang. Teknik pengumpulan data yang digunakan yaitu teknik observasi langsung, teknik pengkuran, dan teknik dokumenter. Teknik analisis yang digunakan adalah bersifat deskriptif kualitatif. Analisis yang digunakan untuk menjawab masalah tersebut menggunakan data kualitatif dan kuantitatif.

\section{HASIL DAN PEMBAHASAN}

Pada proses awal pembelajaran, sudah disepakati bahwa dalam menetapkan kriteria ketuntasan belajar sesuai dengan hasil musyawarah atau rapat kepala sekolah dan guru dengan ketetapan nilai 75 untuk mata pelajaran geografi.

\section{Pra tindakan}

Pra tindakan dilaksanakan bertujuan dari pra tindakan ini adalah untuk mengetahui gambaran khusus mengenai masalah yang ada di dalam kelas yang kemudian masalah tersebut didiskusikan antara peneliti dan guru geografi. Peneliti mengamati aktivitas guru dan siswa dalam pembelajaran dengan model konvensional.

Tabel 1. Ketuntasan Belajar

\begin{tabular}{llll}
\hline No & Hasil Belajar & Jumlah & Persentase \\
\hline 1 & Tuntas & 17 & $51,51 \%$ \\
2 & Tidak Tuntas & 16 & $48,48 \%$ \\
Jumlah & 33 & $100 \%$ \\
\hline
\end{tabular}


Diketahui bahwa persentase ketuntasan siswa yang mampu mencapai nilai KKM atau yang sudah tuntas adalah $51,51 \%$ (17 siswa), sedangkan siswa yang belum tuntas memiliki persentase $48,48 \%$ (16 siswa) dengan nilai rata-rata 67,06. Kondisi seperti ini harus ditangani dengan upaya-upaya perbaikan agar proses dan hasil pembelajaran menjadi lebih maksimal.

2. Siklus 1

Setelah dilakukan tindakan pada siklus I dengan menggunakan alat peraga ular tangga tematik, maka dilakukan test akhir siklus I yang bertujuan untuk mengetahui hasil penggunaan alat peraga ular tangga tematik di kelas XI IPS 4 pada mata pelajaran geografi. Hasil penelitian tindakan kelas (PTK) ini diperoleh berupa data pengamatan (observasi) dan hasil tes.

Tabel 2. Aktivitas Siklus I

\begin{tabular}{lll}
\hline No & Aspek yang diamati & Rata-rata \\
\hline 1 & Persiapan pembelajaran & 1,50 \\
2 & Pendahuluan & 2,0 \\
3 & Kegiatan inti & 2,73 \\
4 & Penutup & 2,66 \\
Jumlah rata-rata & $\mathbf{8 , 8 9}$ \\
Total skor rata-rata & $\mathbf{2 , 2 2}$ \\
\hline
\end{tabular}

Pada tabel pada siklus I aktivitas pembelajaran yang dilakukan guru dapat terlaksana dari nilai maksimal 4 rata-rata yang terlaksana hanya sebanyak 2,22 dengan kategori cukup. Ini dianggap belum sesuai dengan indikator keberhasilan maka dari itu peneliti masih perlu meningkatkan lagi proses pembelajaran mengingat masih ada beberapa tahap yang masih perlu ditingkatkan.

Pada proses pembelajaran siklus I persentase hasil belajar siswa dapat dilihat pada tabel berikut ini :
Tabel 3. Hasil Belajar Siswa Siklus I

\begin{tabular}{|c|c|c|}
\hline No & $\begin{array}{l}\text { Hasil } \\
\text { Siswa }\end{array}$ & Persentase \\
\hline 1 & Tuntas & $72,72 \%$ \\
\hline \multirow[t]{2}{*}{2} & Tidak Tuntas & $27,28 \%$ \\
\hline & Jumlah & $100 \%$ \\
\hline
\end{tabular}

Berdasarkan data yang diperoleh pada siklus I proses belajar mengajar dikatakan belum optimal, siswa belum terbiasa dalam kegiatan belajar mengajar dengan menggunakan alat peraga ular tangga tematik pada mata pelajaran geografi. Guru lupa menyampaikan tujuan pembelajaran di awal kegiatan, guru tidak secara rinci menjelaskan cara memainkan ular tangga tematik, dan guru belum menyimpulkan materi bersama-sama siswa. Sehingga guru dan peneliti memutuskan untuk melanjutkan dan memperbaiki proses pembelajaran serta hasil belajar pada siklus II.

3. Siklus 2

Berdasarkan hasil refleksi siklus I ditemukan proses pembelajaran masih belum berjalan sesuai dengan apa yang diinginkan. Guru dan peneliti melakukan refleksi untuk menentukan faktor-faktor apa saja yang menjadi kendala sehingga proses pembelajaran tidak berjalan sesuai dengan yang diharapkan. Adapun beberapa hal yang menjadikan proses pembelajaran kurang maksimal pada siklus I sebagai refleksi aktivitas guru dalam proses belajar mengajar.

Berdasarkan hasil refleksi siklus I ditemukan proses pembelajaran masih belum berjalan sesuai dengan apa yang diinginkan. Guru dan peneliti melakukan refleksi untuk menentukan faktor-faktor apa saja yang menjadi kendala sehingga proses pembelajaran tidak berjalan sesuai dengan yang diharapkan. 
Observasi dilakukan oleh penulis selama berlangsungnya kegiatan proses pembelajaran pada tindakan siklus II. Pengajar masih melakukan observasi dan menggunakan alat yang sama dengan siklus I, yaitu lembar observasi terstruktur yang telah disiapkan dalam perencanaan, observer akan memberi tanda ceklis $(\sqrt{ })$ pada lembar observasi yang komponen-komponennya terdapat dalam rencana pembelajaran.

\section{Tabel 4. Aktivitas Siklus II}

\begin{tabular}{lll}
\hline No & Aspek yang diamati & Rata-rata \\
\hline 1 & Persiapan pembelajaran & 3,00 \\
2 & Pendahuluan & 3,00 \\
3 & Kegiatan inti & 3,42 \\
4 & Penutup & 3,00 \\
Jumlah skor rata-rata & 12,42 \\
Total skor rata-rata & 3,10 \\
\hline
\end{tabular}

Berdasarkan tabel di atas, aktivitas pembelajaran yang dilakukan guru sudah berjalan baik. Disimpulkan perolehan skor pada setiap indikator pembelajaran yang dilakukan guru dari nilai maksimal 4,00 rata-rata yang terlaksana sebanyak 3,10 dengan kategori baik. Setelah dilakukan tindakan pada siklus II yaitu membahas materi yang bab nya sama dengan materi siklus I yaitu tentang keberagaman budaya Indonesia hanya saja sub bab yang berbeda yaitu materi tentang pembentukan keudayaan nasional, maka dilakukan tes yang bertujuan untuk mengetahui tingkat pemahaman siswa terhadap materi yang telah dipelajari pada siklus II. Tes dilaksanakan pada semua siswa berjumlah 33 siswa.

Berdasarkan hasil observasi proses pembelajaran dan hasil tes pada siklus II, maka melalui alat peraga ular tangga tematik sudah berhasil dilaksanakan dengan baik. Siswa yang memperoleh nilai $\geq 75$ lebih besar dari persentase ketuntasan yang dikehendaki, siswa tuntas sesuai dengan kriteria ketuntasan klasikal yaitu $75 \%$ dari jumlah siswa. Pada proses pembelajaran siklus II persentase hasil belajar siswa dapat dilihat pada tabel berikut ini :

Tabel 5. Hasil Belajar Siklus II

\begin{tabular}{lll}
\hline No & Hasil Belajar & Persentase \\
\hline 1 & Tuntas & $81,81 \%$ \\
\hline 2 & Tidak Tuntas & $18,19 \%$ \\
\hline \multicolumn{2}{l}{ Jumlah } & $\mathbf{1 0 0 \%}$ \\
\hline \multicolumn{2}{r}{ Sumber: Data Olahan Peneliti, 2018}
\end{tabular}

Berdasarkan data yang diperoleh pada siklus II proses belajar mengajar dikatakan sudah cukup optimal, siswa sudah terbiasa dalam kegiatan belajar mengajar dengan menggunakan alat peraga ular tangga tematik pada mata pelajaran geografi.

\section{Peningkatan Hasil Belajar Siswa} Menggunakan Alat Peraga Ular Tangga Tematik

Melalui penggunaan alat peraga ular tangga tematik ini dapat dilihat bahwa siswa lebih memahami materi pelajaran yang disajikan oleh guru. Alat peraga ular tangga tematik ini cocok untuk diterapkan dalam kegiatan belajar mengajar sebagai variasi dalam penyampaian materi oleh guru kepada siswa. Dalam penggunaan alat peraga ular tangga tematik ini peran guru sangat penting, karena guru merupakan fasilitator serta pengaruh pada proses pelaksanaan pembelajaran dan mempersiapkan langkah-langkah serta pemberian nilai terhadap hasil belajar siswa.

Hal ini sejalan dengan hasil jurnal penelitian Iis Maisyaroh pada kajian relevan yang berhasil meningkatkan hasil belajar siswa pada mata pelajaran IPS di kelas VII Mts Al Ikhwan Pondok Aren dengan nilai rata-rata siklus I 65,63 dan rata-rata siklus II 81,50. Berikut alat peraga yang digunakan dalam penelitian dengan ukuran 1 meter persegi. 


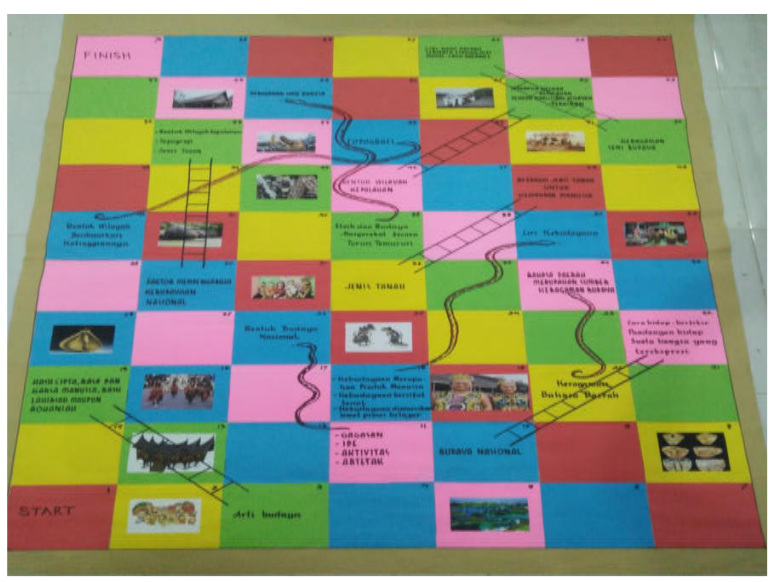

Gambar 2. Alat Peraga Ular Tangga

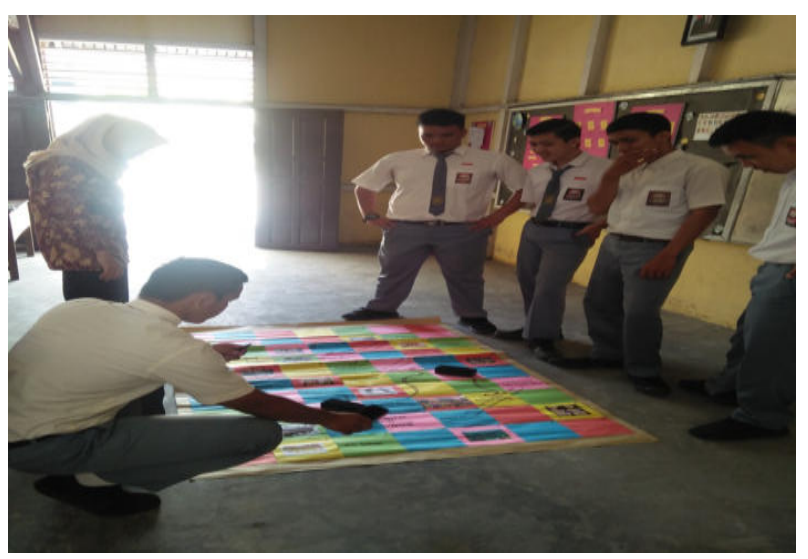

Gambar 3. Pembelajaran Siklus 2

Selanjutnya, keseluruhan hasil belajar siswa pada kegiatan penelitian yang telah dilaksanakan dari awal pelaksanaan kegiatan dengan tahapan perencanaan, pelaksanaan tindakan, observasi, hingga sampai refleksi akhir kegiatan pada siklus I dan siklus II. Dalam keseluruhan hasil belajar tersebut menjadi salah satu tolak ukur dalam keberhasilan pelaksanaan penelitian. Data keseluruhan hasil belajar siswa dapat dilihat pada tabel dibawah ini

Tabel 6. Peningkatan Hasil Belajar Siswa

\begin{tabular}{|c|c|c|c|}
\hline Keterangan & $\begin{array}{c}\text { Pra } \\
\text { Tindak }\end{array}$ & Silus I & Siklus II \\
\hline Tuntas & 17 & 24 & 27 \\
\hline Tidak Tuntas & 16 & 9 & 6 \\
\hline Nilai Tertinggi & 90 & 90 & 90 \\
\hline Nilai Terendah & 35 & 40 & 55 \\
\hline $\begin{array}{l}\text { Ketuntasan } \\
\text { Belajar }\end{array}$ & $51,51 \%$ & $72,72 \%$ & $81,81 \%$ \\
\hline
\end{tabular}

Melalui penggunaan alat peraga ular tangga tematik ini dapat dilihat bahwa siswa lebih memahami materi pelajaran yang disajikan oleh guru. Alat peraga ular tangga tematik ini cocok untuk diterapkan dalam kegiatan belajar mengajar sebagai variasi dalam penyampaian materi oleh guru kepada siswa. Peningkatan hasil belajar siswa dari kegiatan pra tindakan, siklus I, dan siklus II dapat dilihat pada grafik dibawah ini :

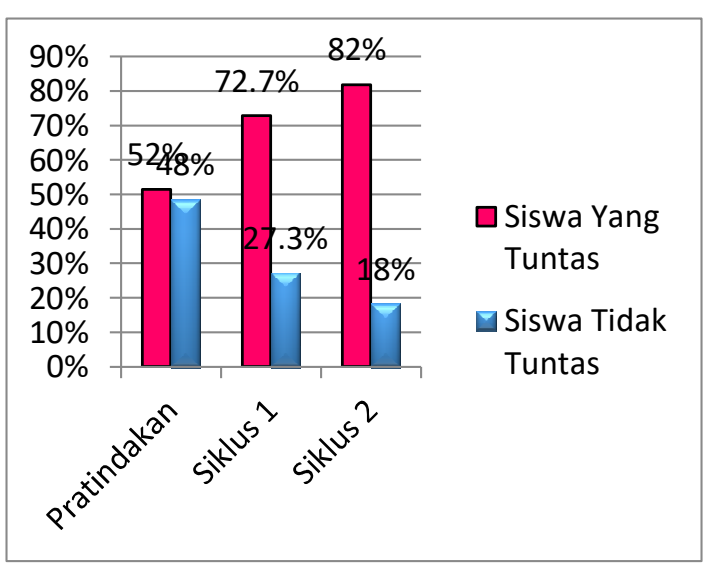

\section{Gambar 4: Grafik Peningkatan Hasil Belajar Siswa}

Berdasarkan grafik di atas, dapat diketahui bahwa dalam pelaksanaan proses pembelajaran mengalami peningkatan. Hal ini dapat dilihat pada setiap proses pembelajaran dari tahap pra tindakan, siklus I, dan siklus II. Pada saat proses pembelajaran dari tahap pra tindakan ke tahap siklus I mengalami peningkatan sebesar $20 \%$ dengan total persentase keseluruhan menjadi $72 \%$. Kemungkinan hal ini dikarenakan siswa belum terbiasa dengan proses pembelajaran menggunakan alat peraga ular tangga tematik yang sudah dilaksanakan dengan nilai rata-rata 72,72 dengan kategori cukup. Sedangkan peningkatan hasil belajar siswa dari siklus I ke siklus II mengalami peningkatan 10\% dengan persentase keseluruhan siswa yang tuntas menjadi $82 \%$. Dengan kata lain peningkatan hasil belajar siswa pada setiap 
tahapanya merupakan kategori peningkatan yang baik dengan nilai rata-rata 78,33.

\section{SIMPULAN}

Kesimpulan secara khusus yaitu penggunaan alat peraga ular tangga tematik pada mapel geografi di kelas XI SMA Negeri 1 Sintang pada siklus I sudah berjalan dengan baik, yaitu dapat dilihat dalam melaksanakan pembelajaran siswa sudah mulai teratur dalam pelaksanaan peraturan permainan alat peraga ular tangga tematik saat pembelajaran. Dan dengan adanya perlakuan pada siklus II siswa jauh lebih mengerti peraturan permainan sehingga siswa lebih bersemangat dalam belajar dengan digunakannya alat peraga ular tangga tematik dalam pembelajaran.

\section{DAFTAR PUSTAKA}

[1] Sardiman. Interaksi dan Motivasi Belajar Mengajar. Jakarta: PT. Rajagrafindo, 2011.

[2] Sudjana, N. Penilaian Hasil Proses Belajar Mengajar. Bandung: PT. Sinar Remaja Rosdakarya offset, 2016.

[3] Sugiyono. Metode Penelitian Kuantitatif Kualitatif dan $R \& D$. Bandung: Alfabeta. 2016.

[4] Alfi and Listiadi, "Pengembangan Permainan Ular Tangga Akuntansi Sebagai Media Pengayaan Pada Materi Ayat Jurnal Penyesuaian Perusahaan Jasa". International Electronic Journal of Akuntansi Education, vol. 3, no. 2, pp. 82-92, 2015. 